\title{
Assessment of Women and Children Vulnerability to Water Use in Low-Income Urban Area of Agbowo Community, Ibadan, Nigeria
}

\author{
Tosin Kolajo Gbadegesin, Olawale Emmanuel Olayide \\ Centre for Sustainable Development, University of Ibadan, Ibadan, Nigeria
}

Email address:

cymbalawesley@gmail.com (T. K. Gbadegesin), waleolayide@yahoo.com (O. E. Olayide)

\section{To cite this article:}

Tosin Kolajo Gbadegesin, Olawale Emmanuel Olayide. Assessment of Women and Children Vulnerability to Water Use in Low-Income Urban Area of Agbowo Community, Ibadan, Nigeria. International Journal of Sustainability Management and Information Technologies. Vol. 5, No. 2, 2019, pp. 29-34. doi: 10.11648/j.ijsmit.20190502.11

Received: May 17, 2019; Accepted: June 20, 2019; Published: December 20, 2019

\begin{abstract}
One of the challenges of urbanization is the increasing vulnerability to quality water supply among households. Low-income urban households lack access to portable water and therefore have to supplement their limited supply with water from sources such as streams, rivers and wells. Whereas when water is available, the quantity is decreasing, and the quality is also compromised mainly due to high population growth accompanied by inadequate infrastructures and poor waste disposal practices. With children and women being most vulnerable to water challenges, the study examined the impacts of water shortages on women and children, investigated the effect of water supply on health outcome of children and looked into effect of water supply challenges on economic productivity of women in low-income urban area of Agbowo Community. The study collected both qualitative and quantitative data. Quantitative data was collected using KOBO collect software - an androidbased application for collecting data while qualitative data was collected by employing Key Informant Interviews (KII). Statistical computations were carried out using Statistical Package for Social Science (SPSS) software. A confidence level of $99 \%$ was used and p-values $\leq 0.01$ was considered statistically significant. The study noted that $74.4 \%$ of the respondents reported children and teenagers $<18$ years old are tasked with the responsibility of getting water for their household while $74 \%$ reported the occurrence of physical deformity as a result of the weight of the water. The study recommended that households should take the responsibility of getting water off children that are too tender and suggested special needs women such as pregnant women and nursing mothers should be put into consideration in development of water supply facilities.
\end{abstract}

Keywords: Low-Income Areas, Access to Water, Household, Urbanization, Vulnerability

\section{Introduction}

Interventions to improve the situation of people living in low-income areas are gaining importance within the development arena particularly in the context of the Sustainable Development Goals (SDGs). Water and sanitation interventions in low-income areas can be placed within the context of tackling poverty, improving living conditions, contributing to economic growth and increasing participation. The United Nations has compared water consumption with its availability and has predicted that by the middle of this century between 2 billion and 7 billion people will be faced with water scarcity. Given this emerging reality, it is little wonder that water has been described as "the oil of the twenty first century", a scarce commodity that will be source of conflict between peoples and nation [11].

In the general Assembly of the human right to water and sanitation, the Assembly established the right of every human being to have access to sufficient water for personal and domestic uses (between 50 and 100 litres of water per person per day), which must be safe, acceptable and affordable (water costs should not exceed 3\% of household income), and physically accessible i.e. the water source has to be within 1,000 metres of the home and collection time should not exceed 30 minutes [4].

Water is central to life. It is part of the five basic human needs: air, water, food, light, and heat. Water is common factor to other four. It is therefore not an understatement to say water is life, because it forms an appreciable proportion 
of all living things including man. Water constitutes about $80 \%$ of animal cells. The human body by weight consists of about $70 \%$ water and several body functions depend on water (UNDP Human development report, 2006). The crucial importance of water to so many aspects of human health, development and well-being led to the inclusion of a specific water-related target in the Millennium Development Goals (MDGs) and Sustainable Development Goals (SDGs) [1].

Water is also the main driver of illnesses such as cholera, dysentery, diarrhoea and typhoid [2]. Unsafe water and poor sanitation are the primary causes for the vast majority of water borne and primarily diarrhoeal diseases. Every year, unsafe water coupled, with a lack of basic sanitation, kills at least 1.6 million children under the age of five years - more than eight times the number of peoples who died in the Asian tsunami of 2004 [17]. Waterborne diseases also inflict significant economic burden through the loss of productivity in the workforce and through increasing national health care costs. Such water related illnesses are often the major cause of premature death in infants. This implies that any process that compromises the supply and distribution of safe water threatens human health, survival, growth and development [13].

Lack of safe drinking water and sanitation are the most serious challenges of the twenty-first century. According to Nanan et al., (2003), inadequate water and sanitation services adversely affect the health and socioeconomic development of communities as it deprives hundreds of millions of people not only of health but also of energy, time, dignity, and quality of life [10]. Sanitation, faulty plumbing, and the use of human excrement as fertilizer lead to water contamination by range of water borne pathogens causing diseases such as diarrhoea, malaria, schistosomiasis and trachoma. These water-related health diseases may be exacerbated by climate change such as higher temperatures, heavier rainfall and changes in climate variability as revealed by the third assessment report of the inter-governmental panel [9].

Africa has the lowest water supply and sanitation coverage of any region in the world. More than 1 in 3 Africans residing in urban areas currently lack access to adequate services and facilities. Africa is also urbanizing faster than any other region and between 1990 and 2025, the total urban population is expected to grow from 300 to 700 million; and by 2020 , it is expected that over $50 \%$ of the population in African countries will reside in urban areas [2].

Given that most of the urban population growth is occurring in communities that are poor and settlements that are informal and unplanned, the task of reaching the unserved has continued to become increasingly difficult. These informal settlements often known as slums, low-income areas, squatter settlements etc. now house between $40 \%$ and $70 \%$ of the urban population and range from high density, squalid inner city tenements to spontaneous, peri-urban settlements lacking legal recognition. Some are more than fifty years old and others are the result of recent urban expansion. Using projections, and bearing in mind that conditions differ between countries and cities, almost half of urban Africans - about 300 million people will be living in slums by 2020 unless current approaches to urban development change radically [7].

A number of studies have looked at water supply challenges. Kalulu et al., (2012) stated that access to potable water is still a very big challenge in Malawi and nearly $50 \%$ of all illnesses recorded in the country are related to water borne diseases [6]. Stone (2009) observed that moving water over long distances from dams or rivers to sustain industries and people living in towns and cities is no easy task, due to the fact that such dams are not conveniently located [12]. The research conducted by Mainganye (2006) discovered that, there was a disparity in the way the villages received water. The supply was interrupted in some villages whereas in other villages there were no interruptions [8].

Hove \& Auxillia (2011) estimated that by 2050 some $40 \%$ the world population could be experiencing water shortages [5]. World Health Organization (2006) outlined that South Africa is one of the countries likely to join water shortage ranks by 2025 [17]. WHO \& UNICEF (2000) reported that the failure to provide safe drinking water $\&$ adequate sanitation services to all people is, perhaps, the greatest development failure of 20th century [16]. Adah \& Abok (2013) discussed a number of weaknesses affecting water supply such as low quality of water services, lack of sustainability of constructed infrastructure, difficulties for targeting the poor and inadequate internal information systems that continue undermining strategies for poverty eradication [1].

Hove \& Auxillia (2011) went on to state that a significant proportion of the Nigerian rural population continue to use rivers, ponds, lakes and harvested rain as their main sources of water supply and blamed limited access to water supplies by a significant proportion of the Nigerian rural population on institutional and socio-economic factors while Obeta and Chukwu (2016) observed these categories of Nigerians are faced great risks to their health and wellbeing due to poor quantity and quality of available water $[5,11]$.

Inadequate access to improved Water, Sanitation and Hygiene (WASH) facilities is one of the recurring problems of low-income urban areas [15]. While access to improved water supply and sanitation are known for urban and rural areas courtesy of several studies conducted in the country, very little is known about the situation in low-income urban areas which makes it extremely difficult to plan for appropriate interventions. It is against this background the study was conducted in Agbowo Community of Ibadan, Nigeria. The community has high incidence of economic poverty accompanied by poor living conditions and large number of slum settlements, haphazard layout, and/or difficult geographical and environmental conditions, and low and unpredictable incomes (earned daily mainly through informal activities) with a high level of socioeconomic differentiation going hand in hand with high unemployment rates (particularly of the youth) and precarious health conditions.

\section{Objectives of the Study}

The general aim of the study is to examine the impacts of water shortages on women and children in low-income urban area of Agbowo Community. Specific objectives of the study are to: 
i. examine women and children vulnerability to water

ii. access the effect of water challenges on children' health and school attendance

iii.access the effect of water challenges on women economic productivity

\section{Methods}

The study was carried out in Agbowo community of Ibadan North Local Government Area of Oyo state, Nigeria. Agbowo which is located on latitude $7^{\circ} 26^{\prime} 39^{\prime \prime} \mathrm{N}$ and longitude $3^{\circ} 54^{\prime} 57^{\prime}$ E. It is one of the largest communities in Ibadan North. The community is a low-income urban area with high incidence of economic poverty accompanied by poor living conditions, limited access to adequate and affordable safe water supply and basic sanitation services, inadequate housing plan, the area is unplanned, haphazard layout, and/or difficult geographical and environmental conditions, prevailing high population densities etc.

Both qualitative and quantitative data were collected using Key Informant Interviews (KII) and structured questionnaires respectively. Quantitative data was collected using KOBO collect software - an android-based application for collecting data. For convenience, 127 households were randomly selected on the basis of severity of water supply challenges. In the second stage, 2 individuals who are 18 years and above were randomly picked from each household and used to collect information on the main source of water, time it takes to collect water, methods used for treatment etc. A total of two hundred and fifty four (254) individuals were randomly sampled for data collection. Also, purposive sampling of influential people in the community such as business persons, religious leaders and traditional leaders was used to identify key informants. The study selected $10 \%$ of the respondents from Sango area to test the validity and reliability of the survey instrument. Statistical computations were carried out using Statistical Package for Social Science (SPSS) software. Data obtained was entered and analysed descriptively using frequencies, tables, graphs and simple percentages. Mean, median, mode and standard deviation were calculated for continuous variables and Chi-square was used to test for associations between categorical variables and proportions. A confidence level of $95 \%$ was used and p-values $\leq 0.05$ considered statistically significant.

\section{Results and Discussion}

\subsection{Socio-Demographic Data of Respondents}

$48 \%$ and $52 \%$ of the respondent were male and female respectively (Table 1). 53.5\% of the respondents were observed to be single while $10.2 \%$ are separated. Majority of the respondents (48\%) possesses secondary education with $48 \%$. $89.8 \%$ rented their apartments of which $53.4 \%$ were living in a room and parlor arrangement.

Table 1. Socio-demographic distribution of respondent I.

\begin{tabular}{lll}
\hline & Frequency & Percent \\
\hline Gender of Respondents & & \\
Male & 122 & 48 \\
Female & 132 & 52 \\
Total & 254 & 100 \\
Marital Status of Respondents & & \\
Single & 136 & 53.5 \\
Married & 92 & 36.2 \\
Separated & 26 & 10.2 \\
Total & 254 & 100 \\
Level of Education & & \\
Primary Education & 41 & 16.1 \\
Secondary Education & 122 & 48 \\
Tertiary Education & 91 & 35.8 \\
Total & 254 & 100 \\
Employment Status & & \\
Yes & 229 & 90.2 \\
No & 25 & 9.8 \\
Total & 254 & 100 \\
House Types & & \\
Single room & 116 & 45.7 \\
Room and parlour & 138 & 54.3 \\
Total & 254 & 100 \\
House Ownership & 268.8 \\
Self & 254 & 100 \\
Rented & & \\
Total & & \\
\hline & & \\
\hline & & \\
\hline
\end{tabular}

Source: Field survey, 2018

32 years old was found to be average age of respondents (Table 2). The average number of children per household was found to be 5 . The mean of number of adults per household was found to be about 9. Mean of monthly income was about $\$ 67$ and the average number of individuals per household was observed to be about 16 .

Table 2. Socio-demographic distribution of respondent (II).

\begin{tabular}{lllll}
\hline Domain & Minimum & Maximum & Mean & Std. Deviation \\
\hline Age of Respondent & 20 & 56 & 32.5512 & 10.01675 \\
No of children per household & 2 & 10 & 4.9567 & 2.63342 \\
No of adult per household & 5 & 20 & 8.9921 & 3.92115 \\
Monthly income (USD) & 28 & 140 & 66.437 & 32.70 \\
No of individuals per household & 11 & 30 & 16.2717 \\
\hline
\end{tabular}

Source: Field survey, 2018

\subsection{Women and Children's Vulnerability to Water Shortage}

In accessing women and children vulnerability to water supply (Table 3 ), $74.4 \%$ of the respondents reported that children and teenagers $<18$ years old are tasked with the responsibility of getting water for their household. $74 \%$ reported the occurrence of physical deformity as a result of the weight of the water. The best time to get water was found 
to be early morning as reported by $81.9 \%$ of the respondents while transportation means such as vehicle or motorcycle have rarely being employed (10.2\%) to convey water.

Table 3. Women and children vulnerability to water (I).

\begin{tabular}{lll}
\hline Responsible for fetching water & & \\
\hline Domain & Frequency & Percent \\
\hline Children (<18yrs old) & 189 & 74.4 \\
Adult (>18yrs old) & 65 & 25.6 \\
Total & 254 & 100 \\
Physical deformity occurrence & & \\
Yes & 188 & 74 \\
No & 66 & 26 \\
Total & 254 & 100 \\
Best time to get water & & \\
Very Early Morning & 208 & 81.9 \\
Evening/Night & 46 & 18.1 \\
Total & 254 & 100 \\
Use of transportation & & \\
Yes & 26 & 10.2 \\
No & 228 & 89.8 \\
Total & 254 & 100 \\
\hline
\end{tabular}

Source: Field survey, 2018

From Table 4 below, it was discovered that the average time spent in getting water can be 16 minutes with standard deviation of 15 minutes. It was also gathered that the average number of times water sources were visited per day was about 3 times. The minutes trekked to reach water sources was reported to be as low as 2 minutes and as high as 20 minutes.

Table 4. Women and children vulnerability to water supply (II).

\begin{tabular}{lllll}
\hline Domain & Minimum & Maximum & Mean & $\begin{array}{l}\text { Std. } \\
\text { Deviation }\end{array}$ \\
\hline $\begin{array}{l}\text { Minutes spent in getting } \\
\text { water }\end{array}$ & 1 & 60 & 16.378 & 15.61135 \\
$\begin{array}{l}\text { No of times water source(s) } \\
\text { is visited per day }\end{array}$ & 1 & 10 & 3.1181 & 2.66914 \\
$\begin{array}{l}\text { No of minutes trekked to } \\
\text { reach water source(s) }\end{array}$ & 2 & 20 & 7.2835 & 5.84909 \\
\hline
\end{tabular}

Source: Field survey, 2018

\subsection{Assessment of the Effect of Water Supply on Children' Health and School Attendance}

About $79.9 \%$ of the respondent reported the water quality do affect their children' health (Table 5). Common illness was found to be malaria at $33.3 \%$, cholera at $15 \%$, diarrhea at $26 \%$ and typhoid at $15.7 \%$. Majority of the respondents $(71.7 \%)$ reported self-medication as the usual treatment method during emergency.

Table 5. Effect of water supply on children health (I).

\begin{tabular}{lll}
\hline \multicolumn{2}{l}{ Negative Effect on Children' Health } & \\
\hline Domain & Frequency & Percent \\
\hline Yes & 203 & 79.9 \\
No & 51 & 20.1 \\
Total & 254 & 100 \\
Common illness & & \\
Malaria & 123 & 48.4 \\
\hline
\end{tabular}

\begin{tabular}{lll}
\hline \multicolumn{2}{l}{ Negative Effect on Children' Health } & \\
\hline Domain & Frequency & Percent \\
\hline Typhoid & 40 & 15.7 \\
Malaria and Typhoid & 66 & 26 \\
Total & 229 & 90.2 \\
Treatment method during emergency & \\
Self-medication & 182 & 71.7 \\
First Aid & 26 & 10.2 \\
Phone a doctor & 46 & 18.1 \\
Total & 254 & 100 \\
\hline
\end{tabular}

Source: Field survey, 2018

The mean and standard deviation of number illness per term was found to be about 3 times and 1 times respectively (Table 6). The average frequency of illness was found to be about 5 times. Of the illnesses, study showed that an average of 3 can be attributed to water. The average trekking distance to medical facility was found to be about 18 minutes.

Table 6. Effect of water supply on children health (II).

\begin{tabular}{lllll}
\hline Domain & Minimum & Maximum & Mean & $\begin{array}{l}\text { Std. } \\
\text { Deviation }\end{array}$ \\
\hline No of illness per term & 1 & 5 & 2.7192 & 1.16252 \\
Frequency of illness & 1 & 9 & 5.1478 & 2.61334 \\
$\begin{array}{l}\text { Those attributed to water } \\
\text { Trekking time to medical }\end{array}$ & 1 & 6 & 3.202 & 1.6209 \\
facility & 2 & 45 & 18.4055 & 12.36456 \\
\hline
\end{tabular}

Source: Field survey, 2018

On children' school attendance (Table 7), 82.3\% of the respondents reported water supply affect their children' school attendance and only $9.8 \%$ reported their children are yet to miss school.

Table 7. Effect of water supply on children' school attendance (I).

\begin{tabular}{lcc}
\hline & Frequency & Percent \\
\hline \multicolumn{2}{l}{ Significance of water supply to Children' school attendance } \\
Yes & 208 & 82.3 \\
No & 20 & 8.2 \\
Cannot say & 25 & 9.8 \\
Total & 254 & 100 \\
Number of times they miss school per term & \\
0 & 25 & 9.8 \\
2 & 72 & 28.3 \\
3 & 40 & 15.7 \\
5 & 71 & 28 \\
Total & 208 & 81.9 \\
\hline
\end{tabular}

Source: Field survey, 2018

Looking that the numbers of times children have missed school (Table 8), an average of about 6 times was recorded. Of these, an average of 3 can be attributed to water supply challenges. The average time spent in trekking to school was found to be about 40 minutes. When time spent in trekking was compared to time spent when means of transportation was employed, an average of 22 minutes was found.

Table 8. Effect of water supply on children' school attendance (II).

\begin{tabular}{lllll}
\hline Domain & Minimum & Maximum & Mean & Std. \\
\hline
\end{tabular}




\begin{tabular}{lcccc}
\hline & & & & Deviation \\
\hline $\begin{array}{l}\text { No of times they missed } \\
\text { school }\end{array}$ & 0 & 9 & 5.8798 & 2.91589 \\
$\begin{array}{l}\text { Attributed to water } \\
\text { supply }\end{array}$ & 2 & 6 & 3.6393 & 1.24078 \\
$\begin{array}{l}\text { Time spent in trekking to } \\
\text { school }\end{array}$ & 10 & 70 & 39.38 & 21.147 \\
$\begin{array}{l}\text { Time spent when } \\
\text { transportation is used }\end{array}$ & 1 & 40 & 22.0673 & 12.51686 \\
\hline
\end{tabular}

Source: Field survey, 2018

\subsection{Assessment of the Effect of Water Supply on Women Economic Productivity}

Table 9. Effect of water supply on women economic productivity.

\begin{tabular}{lll}
\hline \multicolumn{2}{c}{ Frequency } & Percent \\
\hline \multicolumn{2}{l}{ Whether wife/mother is working } & \\
Yes & 254 & 100 \\
Nature of job & & \\
Artisan & 90 & 35.4 \\
Self-employed & 46 & 18.1 \\
Teacher & 26 & 10.2 \\
Trading & 92 & 36.2 \\
Total & 254 & 100 \\
Yes & 229 & 90.2 \\
\hline
\end{tabular}

\begin{tabular}{lll}
\hline & Frequency & Percent \\
\hline Whether wife/mother is working & \\
No & 25 & 9.8 \\
Total & 254 & 100 \\
Yes & 168 & 66.1 \\
No & 66 & 26 \\
Total & 234 & 92.1 \\
\hline
\end{tabular}

Source: Field survey, 2018

All the respondents reported their wife/mother to be working (Table 9). Of these, $35.4 \%$ were artisans, $10.2 \%$ were teachers and $36.2 \%$ were traders. $90.2 \%$ reported water availability to be crucial to their job productivity while $66.1 \%$ reported inadequate water supply have prevented them from working before.

\subsection{Significant relationship between school absence and proportion attributed to water scarcity}

Taking $1 \%$ probability level, we can see that Pearson correlation coefficient, $\mathrm{r}$, is 0.636 , and that is statistically significant $(\mathrm{p}=0.000)$. This implies that there is significant relationship between number of times children have missed school and the proportion that can be attributed to water supply.

Table 10. Showing Pearson correlation coefficient, $r$, between number of times children have missed school and how many of these can be attributed to water supply.

\begin{tabular}{llll}
\hline Correlations & & & \\
\hline & & No of times children have missed school & No that can be attributed to water supply \\
\hline $\begin{array}{l}\text { No of times children have } \\
\text { missed school }\end{array}$ & Pearson Correlation & 1 & $.636^{* *}$ \\
& Sig. (2-tailed) & & .000 \\
& $\mathrm{~N}$ & 208 & 183 \\
\hline
\end{tabular}

Source: Field survey, 2018

**. Correlation is significant at the 0.01 level (2-tailed).

\section{Conclusions}

The motivation for this study arose from the need to understand women and children vulnerability to water supply challenges in low-income urban area of Agbowo. The sociodemographic information revealed the areas as a low-income with low literary level as people live in more of scattered settlement. Households having high population density with low earning potential further enumerate the characteristics of low-income communities as most live on less than $\$ 1$ per day. The study shows that their job reliability is poor as many moved from one job to another at regular intervals.

A household was seen to have as much as 10 children under the age of 18 and as low as 2 children under the age of 18. In the same vein, a household was seen to have as much as 20 individuals greater than 18 years old. Lowest income was found to be $\$ 28$ and one with highest earning potential earns about $\$ 140$.

Assessments of women and children' vulnerability to water supply showed that $74.4 \%$ of respondent stated children and teenagers under 18 years of age are tasked with responsibility of getting water. About $74 \%$ reported having to carry water had resulted in physical deformity. Looking at the number of times children have missed school, a maximum of 9 times was obtained of which 6 of it can be attributed to water unavailability. Taking $1 \%$ probability level, Pearson correlation coefficient, $r$, is 0.636 , which is statistically significant $(\mathrm{p}=0.000)$. This implies that there is significant difference between number of times children have missed school and how many of these can be attributed to water unavailability.

Also, all the respondents reported either their wife or mother to be working. Of these, $35.4 \%$ were artisans, $10.2 \%$ were teachers and $36.2 \%$ were traders. $90.2 \%$ reported water availability to be crucial to their wife/mother job productivity while $66.1 \%$ reported inadequate water supply have prevented them from working before.

Therefore, not being able to meet growing water demand as the population in Agbowo community continues to increase suggests the need for immediate solution. Making water available will not record high success if the water is not of good quality. The poor quality water was evident with high incidence of diseases and frequent reduction in school attendance of children. Effect of water non-availability on children' health further which shows why children are vulnerable as most develop illnesses such as malaria, typhoid, cholera and diarrhea. 
Effort need to be made to reduce distance to water sources and make water services close to people residence. This will address the need to trek long distances to get water. Closeness of medical facilities will also address watercomplicated illnesses as this will reduce self-medication practices widely adopted. This will also prevent children from missing school and having unexpected health complications.

Regulation on the age a child can handle water responsibility for his household and what would be his/her carrying capacity needs to be put in place. Households should take responsibility of getting water off children that are too tender. If this is done, the issue of physical deformity will might be addressed. The can be achieved by preventing children less than 15 years of age from fetching water. In the same vein, water facilities provided by government or donor agencies should be easily accessible to children in case of emergencies. Economic productivity of women is essential to household survival; therefore risks of access to water need to be reduced for women. This can be achieved if water is made available at a trekking time less than 5 minutes from home. Also, special needs women such as pregnant women and nursing mothers should be put into consideration in development of water supply facilities.

\section{Acknowledgements}

Our utmost appreciation goes to God Almighty for His goodness to us. Our heartfelt gratitude also goes Africa Water Association (AfWA) for funding this study. We are glad to extend our gratitude to the Director of University of Ibadan Centre for Sustainable Development (CESDEV) Prof. Olaranwaju Olaniyan. Special thanks to Temitope Ogunweide for working with me during data collection exercise and to people like Omotola Ogundipe for review done. Special thanks to Centre for Sustainable Development (CESDEV) and University of Ibadan, Nigeria for providing the platform for this study.

\section{References}

[1] Adah, P. D and Abok G. 2013. Challenges of Urban Water Management in Nigeria: The Way Forward. Journal of Environmental Sciences and Resource Management Volume 5 , Number 1

[2] Bradley J, Holmes B, Thomas S. (2007). Water quality snapshot 2001-2002: Historic baseline data for the Mount Lofty Ranges Watershed, Adelaide, USA.

[3] Dzikus, A. (2001)."Managing Water for African Cities: An Introduction to Urban Water Demand", Regional Conference on the Reform of the Water Supply and Sanitation Sector in
Africa - Enhancing Public-Private Partnership in the Context of the Africa Vision for Water (2025), Kampala, Uganda

[4] Hope RA (2006). Evaluating water policy scenarios against the priorities of the rural poor. World Development, Science of the Total Environment, 34 (1):167-179.

[5] Hove Mediel \& Auxillia Tirimboi. 2011. Assessment of Harare Water Service Delivery. Journal of Sustainable Development in Africa (Volume 13, No.4, 2011) ISSN: 15205509 Clarion University of Pennsylvania, Clarion, Pennsylvania

[6] Kalulu K, Hoko Z, Mayo AW, Kumwenda S (2012). Sustainability of Community Based Water Management in Mulanje District, Malawi. Basic Appl. Sci. Res. J. Text Road Publications.

[7] Majuru B, Michael-Mokoena M, Jagals P, Hunter PR (2011). Health impact of Small-community water supply reliability. Int. J. Hygiene Environ. Health, 214(2):162-166.

[8] Mainganye, T. J (2006). Local Governments ${ }^{\text {ee }}$ intervention strategies to improve service delivery: Case of rural areas of Vhembe District, South Africa, MDEV. Dissertation, University of Limpopo.

[9] Murinda S. (2011). Comparative Assessment of Performance of Urban Water Supply Systems in Small Towns in Zimbabwe: MSc. thesis. University of Zimbabwe.

[10] Nanan, White, Azam, Afsar, Hozhabri 2003: D. Nanan, F. White, I. Azam, H. Afsar and S. Hozhabri, "Bulleting of the World Health Organization" (Washington D. C., Mar.), 81 (3), 160 .

[11] Obeta Michael Chukwuma. (2016). Patterns and problems of domestic water supply to rural communities in Enugu State, Nigeria Hydrology and Water Resources Unit, Department of Geography, University of Nigeria, Nsukka, Enugu State, Nigeria. Received 11 July, 2016; Accepted 21 September, 2016.

[12] Stone, T. (2009). Water supply: Thinking strategically, IMIESA.

[13] UNICEF/ WHO. (2004). Meeting the MDG drinking water and sanitation target - A mid-term assessment of progress: United Nations Children's Fund and World Health Organisation, pp. 36

[14] UNDP Human Development Report (2006): Beyond Scarcity: Power, Poverty and the Global Water Crisis. Available at http:/hdr.undp.org/hdr2006/ (accessed on 19th September 2012).

[15] Water Aid (2008). Tackling the Silent Killer (London), 4, 6-9.

[16] WHO and UNICEF (2000). The Global Water Supply and Sanitation Assessment 2000 (Geneva, New York: WHO, UNICEF).

[17] World Health Organization (2006): Getting Africa on Track to Meet the Millennium Development Goals. 